Portland State University

PDXScholar

$5-1975$

\title{
Variations of the form and image of the modern hero
}

Lee Hunt

Portland State University

Follow this and additional works at: https://pdxscholar.library.pdx.edu/open_access_etds

Part of the Art and Design Commons Let us know how access to this document benefits you.

\section{Recommended Citation}

Hunt, Lee, "Variations of the form and image of the modern hero" (1975). Dissertations and Theses. Paper 2121.

https://doi.org/10.15760/etd.2119

This Thesis is brought to you for free and open access. It has been accepted for inclusion in Dissertations and Theses by an authorized administrator of PDXScholar. Please contact us if we can make this document more accessible: pdxscholar@pdx.edu. 
AN ABSTRACT OF THE THESIS OF Lee Hunt for the Master of Fine Arts in sculpture presented May 7, 1975.

Title: Variations on the Form and Image of the Modern Hero. APPROVED BY MEMBERS OF THE THESIS COMMITTEE:

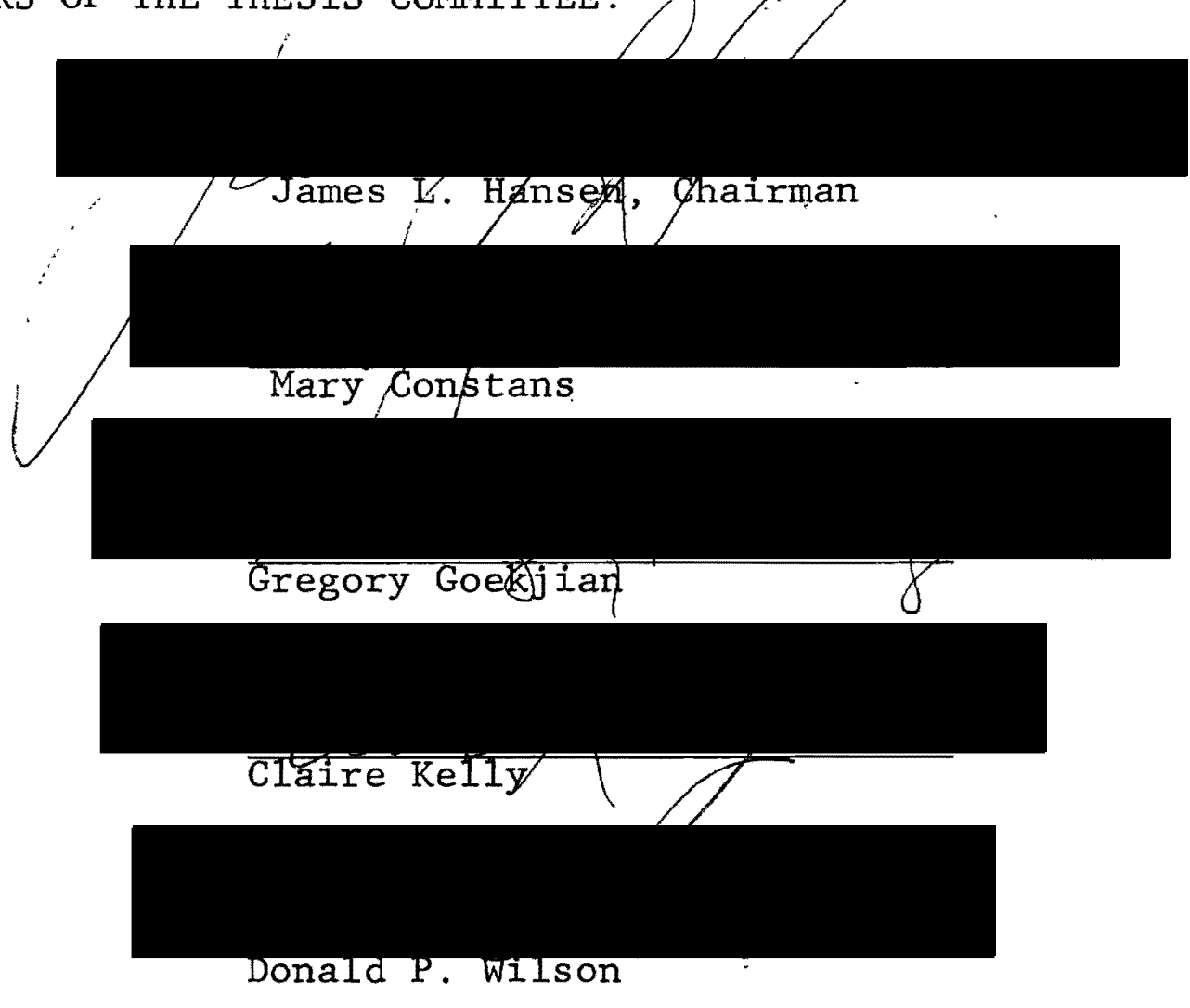

The thesis discusses six sculptures completed during the period of study from October of 1973 to May of 1975 and presented at the White Gallery, April 28, 1975-May 13, 1975. 


\title{
VARIATIONS OF THE FORM AND IMAGE \\ OF THE MODERN HERO
}

\author{
by \\ Lee Hunt
}

A thesis submitted in partial fulfillment of the requirements for the degree of

\author{
MASTER OF FINE ARTS \\ in \\ SCULPTURE
}

Portland State University

1975 
TO THE OFFICE OF GRADUATE STUDIES AND RESEARCH:

The members of the committee approve the thesis of Lee Hunt presented May 7, 1975:

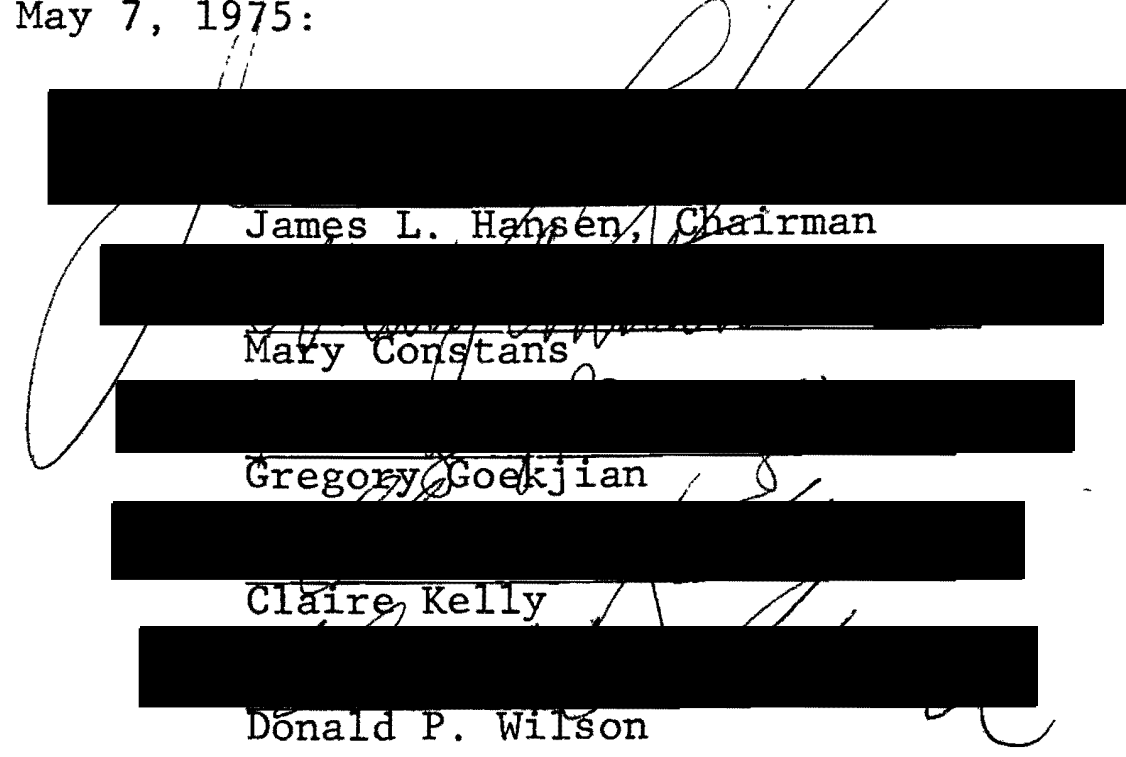

APPROVED :

Frederjec Heide1, Department of Art and Architecture

gavid 1. Clark, Dean of Graduate Studies and Research 
TABLE OF CONTENTS

LIST OF FIGURES. . . . . . . . . . . . . . . iv

\section{CHAPTER}

I. INTRODUCTION. . . . . . . . . . . . . 1

II. DESCRIPTION AND ANALYSIS OF THE SCULPTURES 6

III. METHODS AND TECHNIQUES. . . . . . . . . 23

IV. CRITIQUE AND CONCLUSIONS. . . . . . . 25 


\section{LIST OF FIGURES}

FIGURE

PAGE

I "Death of the Virgin" (detail) 2

II "Death of the Virgin" (detail). 4

III "Modern Christ" 5

IV "Roethke's Dance" 7

$\mathrm{V}$ "Group of One" . 9

VI "Group of One" 10

VII "Group of One" 11

VIII "Death of the Virgin" 13

IX "Death of the Virgin" 14

X "Death of the Virgin" 15

XI "Death of the Virgin" 16

XII "Apollo" 17

XIII "Apo11o" 18

XIV "Apollo" 19

XV "Nietzsche" 20

XVI "Nietzsche" 21 


\section{CHAPTER I}

\section{INTRODUCTION}

In sculpture, each form is integral, and form yields to correspondence with other forms, characterizing the piece. In my work, I recognize a correspondence of forms that is at once resolution and increased tension. The eye travels around the piece in a sort of panoramic justice, but the recognition of limbs or heads can cause tension. A view of two legs from the knees down may startle you; they are both left legs. "Oh, I see; they belong to different figures."

My nature loves irony, the mischief of meanings. Perhaps this is a means of capturing life which is growth and movement in something relatively changeless and static. The tension of forms and of their implications to the viewer allows the sculpture to come alive each time it is viewed. The idea of expressing life is very important to me. If I were to delineate a message in my work it would probably be to express the folly of human presumptions and at the same time affirm mankind's attempts to understand. I am trying to make a new image of the hero as one who is ridiculous in his foolish drama but loveable, and above all dignified by his earnestness. The expression depends on posture, body type, and gesture in the context of stereotypical images, that is, in the context of art history. At times the work 


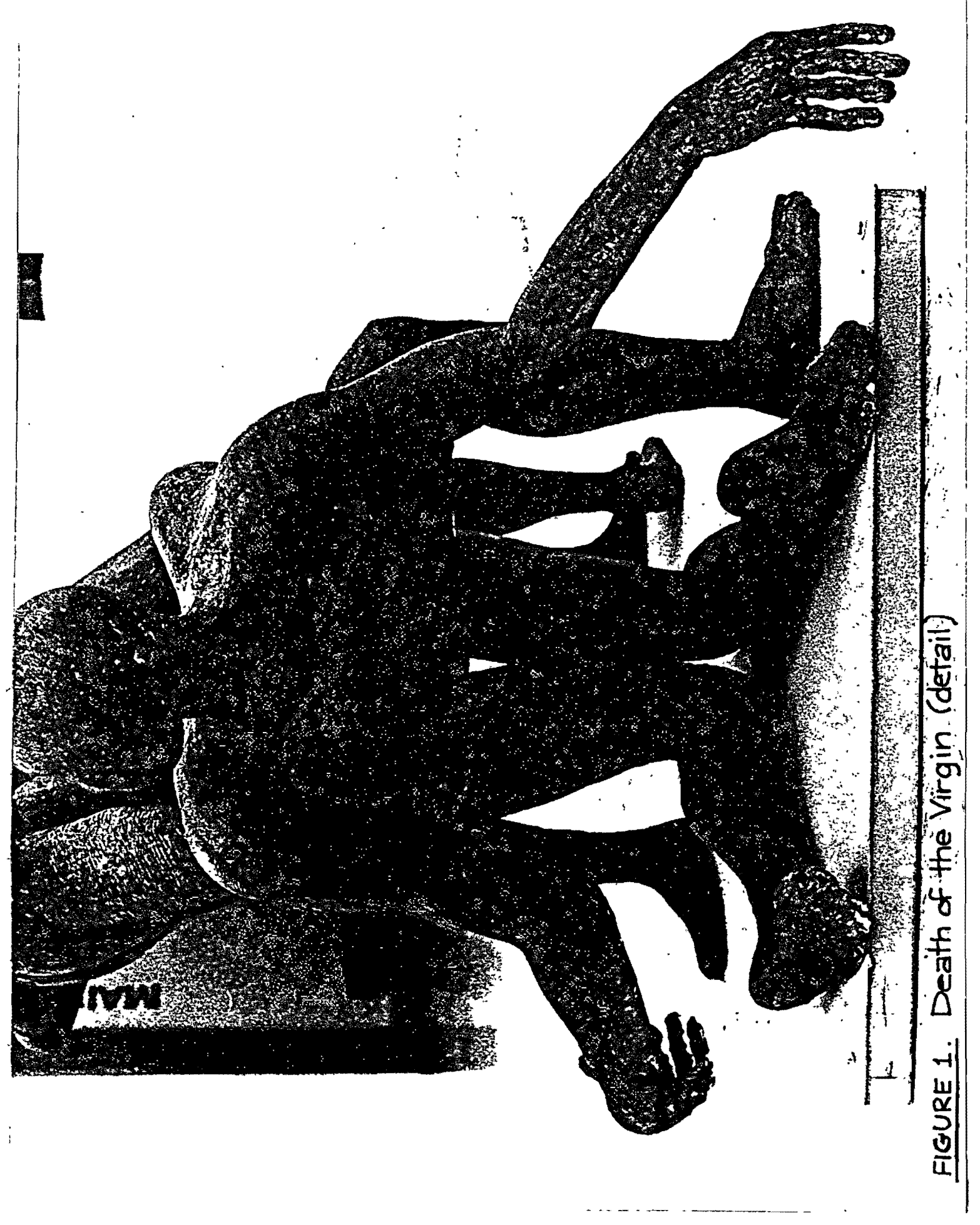


has a stop-action quality as in single-frame images of a dance or stage play, and at times it has a stable quality: like someone posed or permanent. In both extremes, the animated and theatrical ("Death of the Virgin") and the stable ("Modern Christ"), the real action takes place in the viewer, who will, I hope, be haunted into balancing the contradictory elements in each piece. 


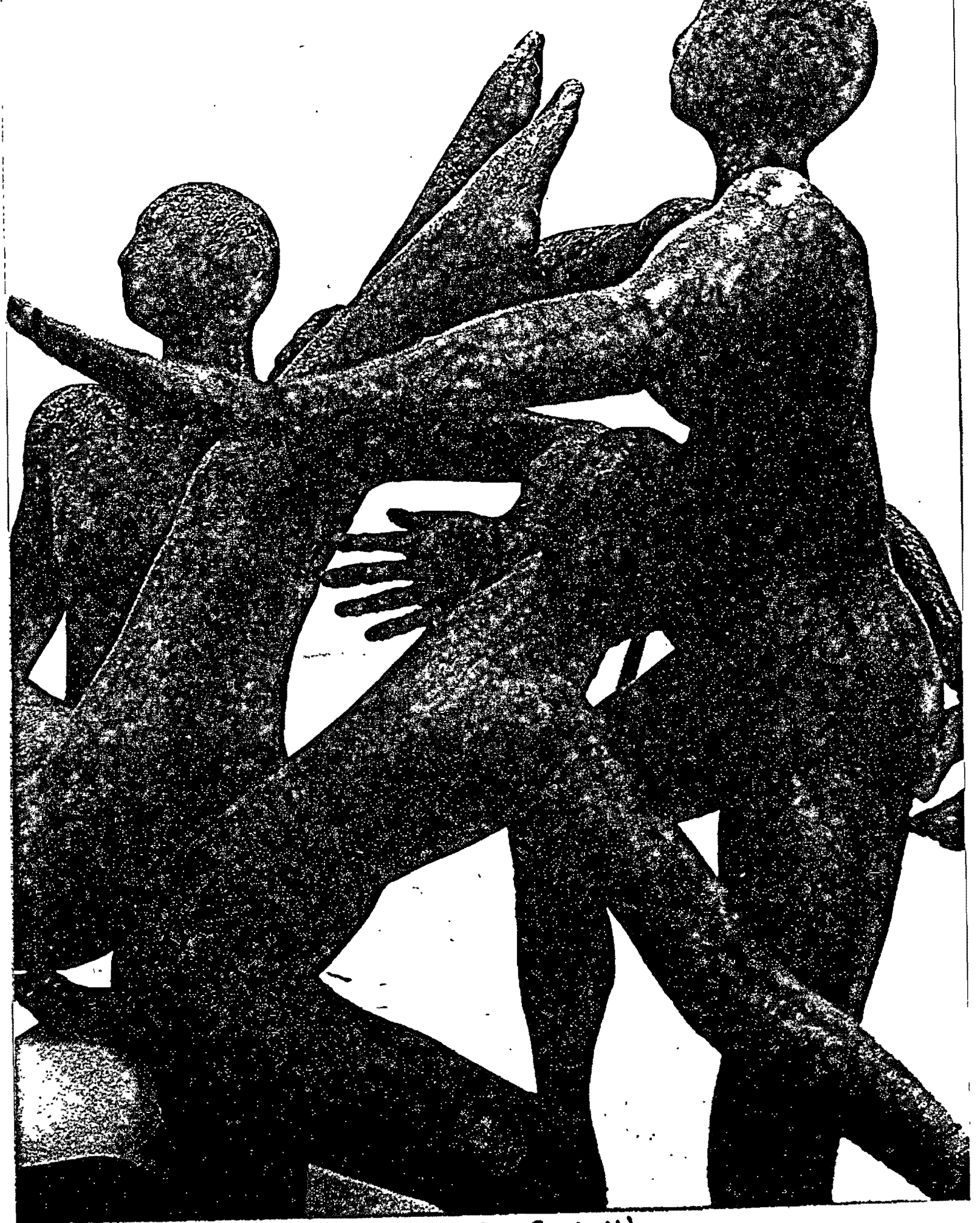

FIQURE 2. Death of the Virgin (detail) 

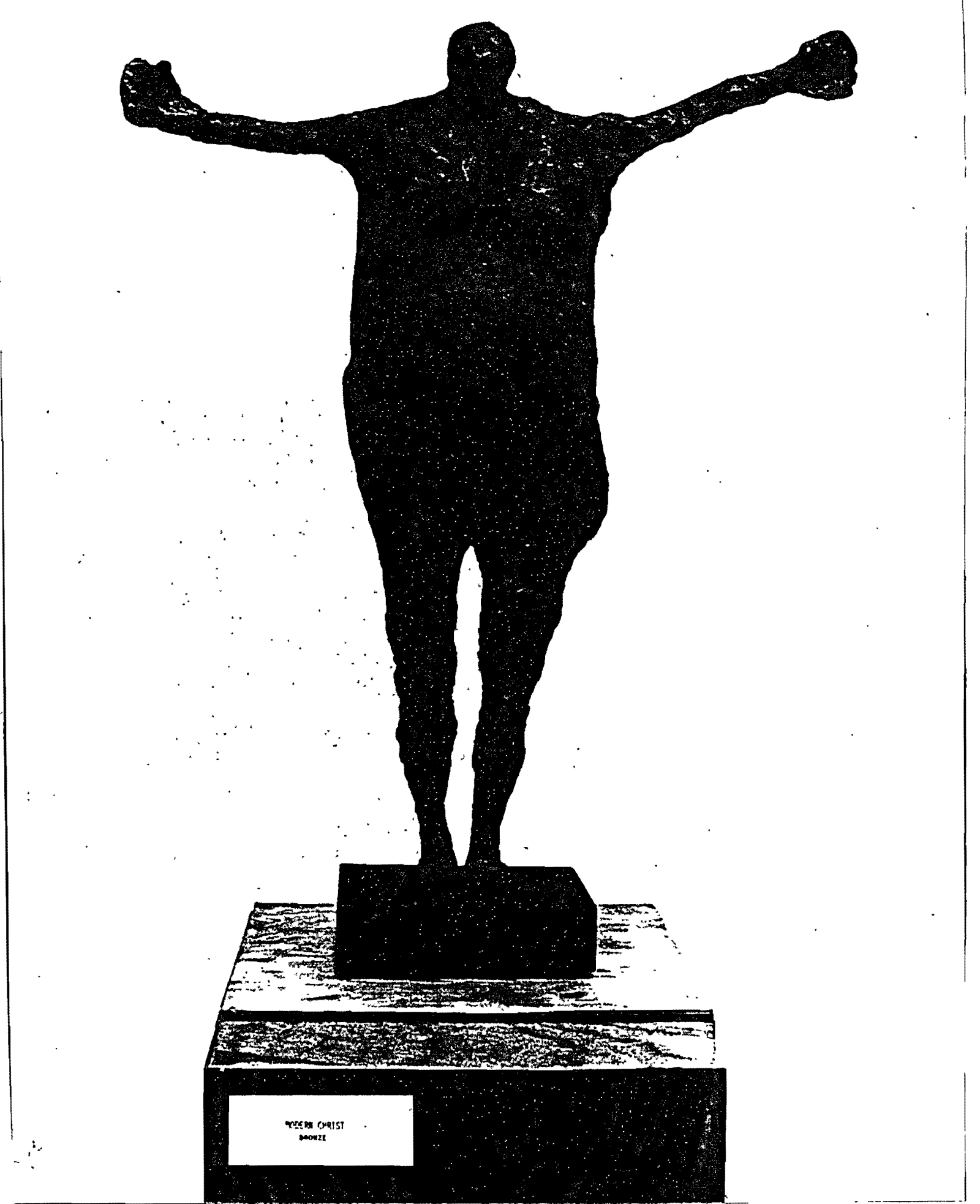

FIGURE 3. Modern Christ 
CHAPTER II

\section{DESCRIPTION AND ANALYSIS OF THE SCULPTURES}

The Christ figure is perhaps most obviously dependent on a visual stereotype. The outstretched arms, half blessing, half reaching, do not express the suffering of usual Christ figures in that pose. Nor does the overfed and massive body express the wan physical defeat that we would expest. But the image translated to this time may indeed be a kind of suffering and physical defeat that is closer to our understanding in that it reflects a more common approach to sacrifice.

Visual1y, "Roethke's Dance" was influenced by romanesque art. I love the extremes, somewhat odd, funny but serious, in the romanesque. The title refers to Roethke's poem, "Four for Sir John Davies":

Is that dance slowing in the mind of man That made him think the universe could hum? The great wheel turns its axle when it can; I need a place to sing, and dancing-room, And I have made a promise to my ears I'11 sing and whistle romping with the bears.

The poem makes me see a hopeful romantic, a dinosaur in his time, who believes that this pendulous movement between extremes can be a pulse-like dance which loves life. I tried to capture fluidity and instability in conjunction with a powerful, potent image, to show the strong and per- 


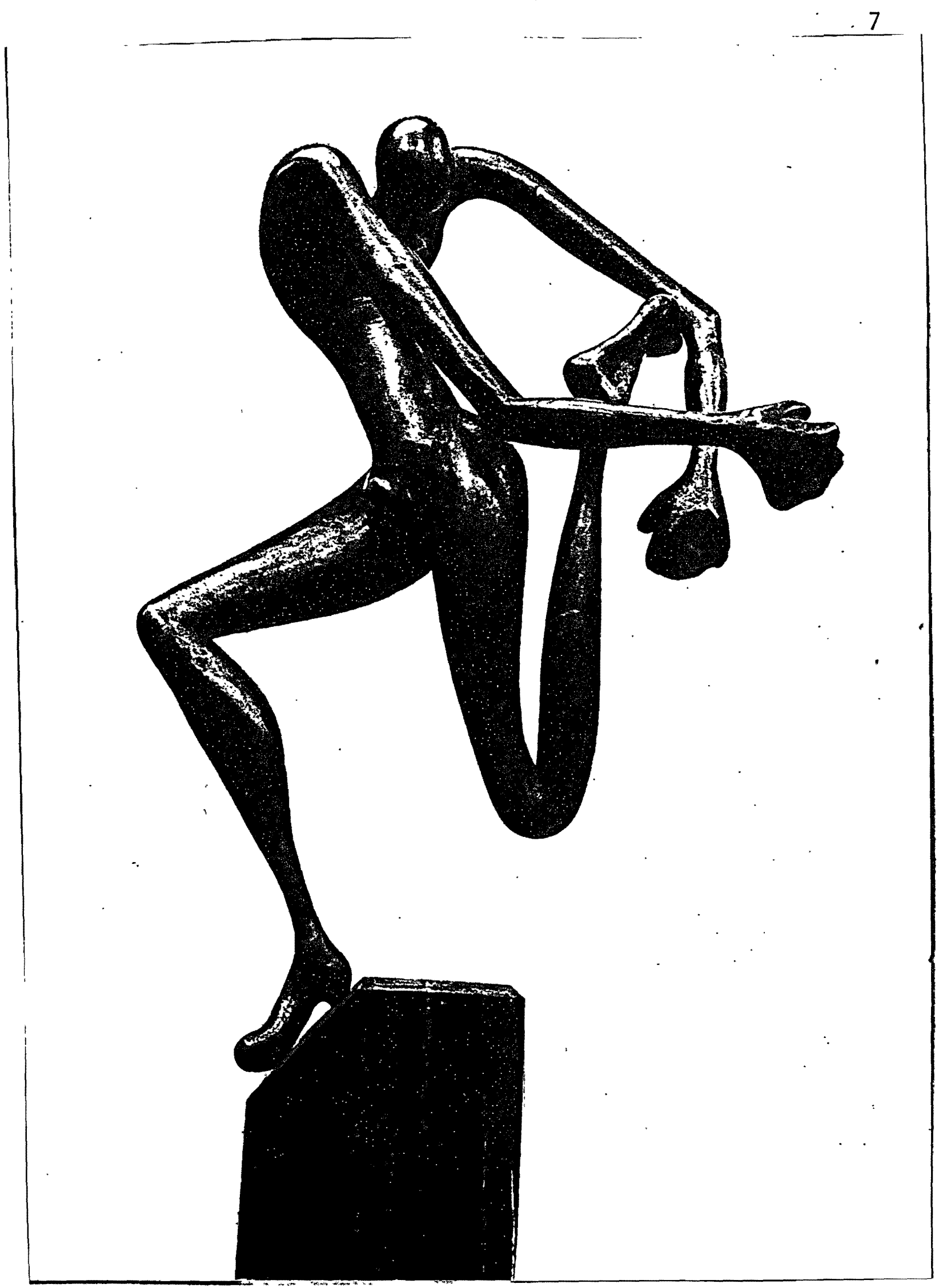

FIGURE 4: Roethke's Dance 
haps impossible dance, danced like writing on air. This piece, more than the other sculptures, works in silhouette; it is the most two dimensional because it is small enough to focus out the forms. The larger, "Group of One" sculpture would be more silhouette-like except that its size makes one focus in forms:

The fact that I chose to work larger than "Modern Christ" and "Roethke's Dance" is a result of my subject -the human figure. I wanted them to be the same size as living humans so that we could more easily identify with them. The smaller ones can seem like dolls or children in that it is easier for us to detatch ourselves, thinking outweighing intuition.

My first large piece, "Group of One", intends to satirize the attitude that we are pulled by forces that are seperate from us, that we are martyrs to relationships with other people. I see the figures as the central figure with imaginary figures pulling on him. They are not lifelike though they are large; they are more totemic, stilted in both senses, and apparently frozen in the gesture, the attitude.

The most recent large sculpture, on the other hand, intends to imply movement, even to the point of using. four figures on the same plane to depict change in two figures over time. In other words, I think of the two male figures in "Death of the Virgin" as the same individual and the two 


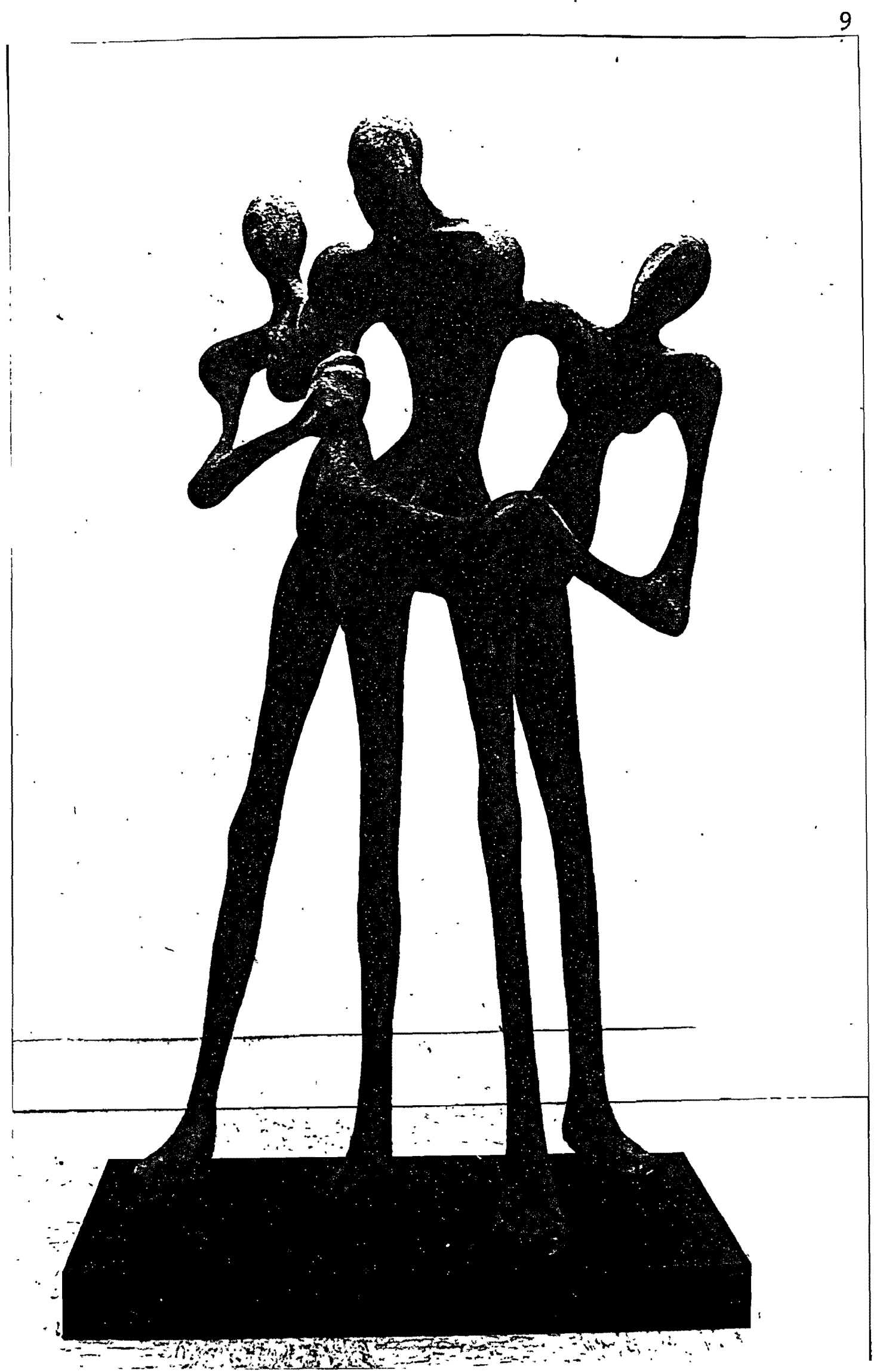

FIGURE 5. Group of One 


$$
118
$$




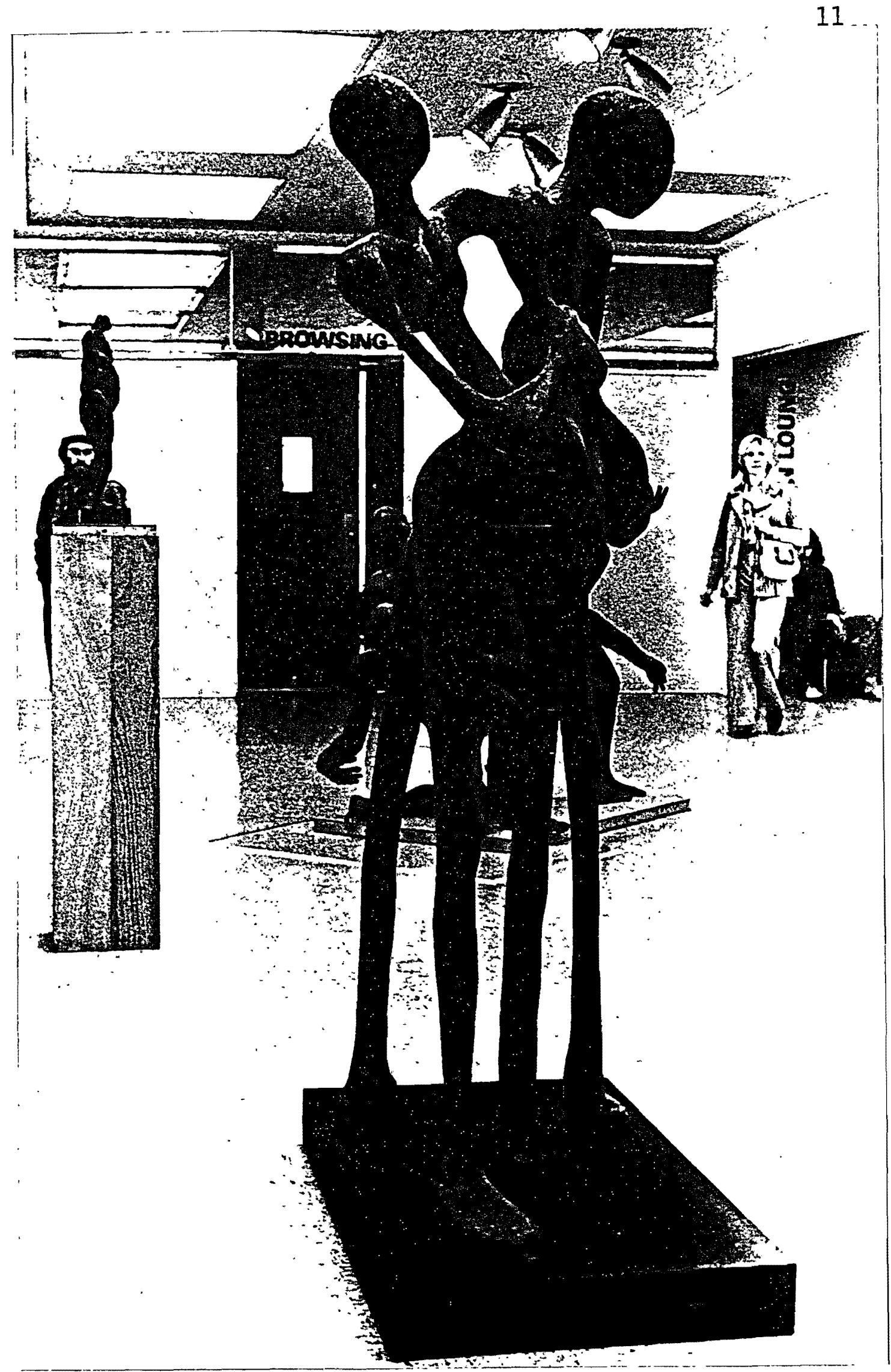

FIGURE 7. Group of One 
female figures as the same individual. Only they assume two extremely opposing gestures as if to indicate evolution from one to the other or a back and forth change.

Depending on medieval art for thematic reference, the piece makes ridiculous certain heroic types by the absurdities of their gestures. Still it intends respect for their dramatic intensity, for their partial grace and beauty which is circumscribed by the folly of playing out such limited roles. In addition, the piece juxtaposes extreme gestures with a serene surface and bulkiness with negative patterns in space which increases the number of elements which must be balanced. It is difficult in terms of heroic images, though the disquiet it causes may be lively. and exciting.

"Apo110" and "Nietzsche" are simpler to view because they are single figures. "Apollo" is not the Greek's perfect god. I mean that we worship decaying images; they are strong but impotent; they have no face. Still they are beautiful to contemplate.

"Nietzsche's" body is a combination of types: Apollonian and Dionysian. He has powerful legs, his animal source, but his upper body is totally subservient to his prominent head and hands. Even in his lower body, the ralled-over feet show the effect of his ruling intellect. That is to say, the head wins. I wanted to show a brilliant and sensitive man who believed in the superiority of the sensual instinct but 


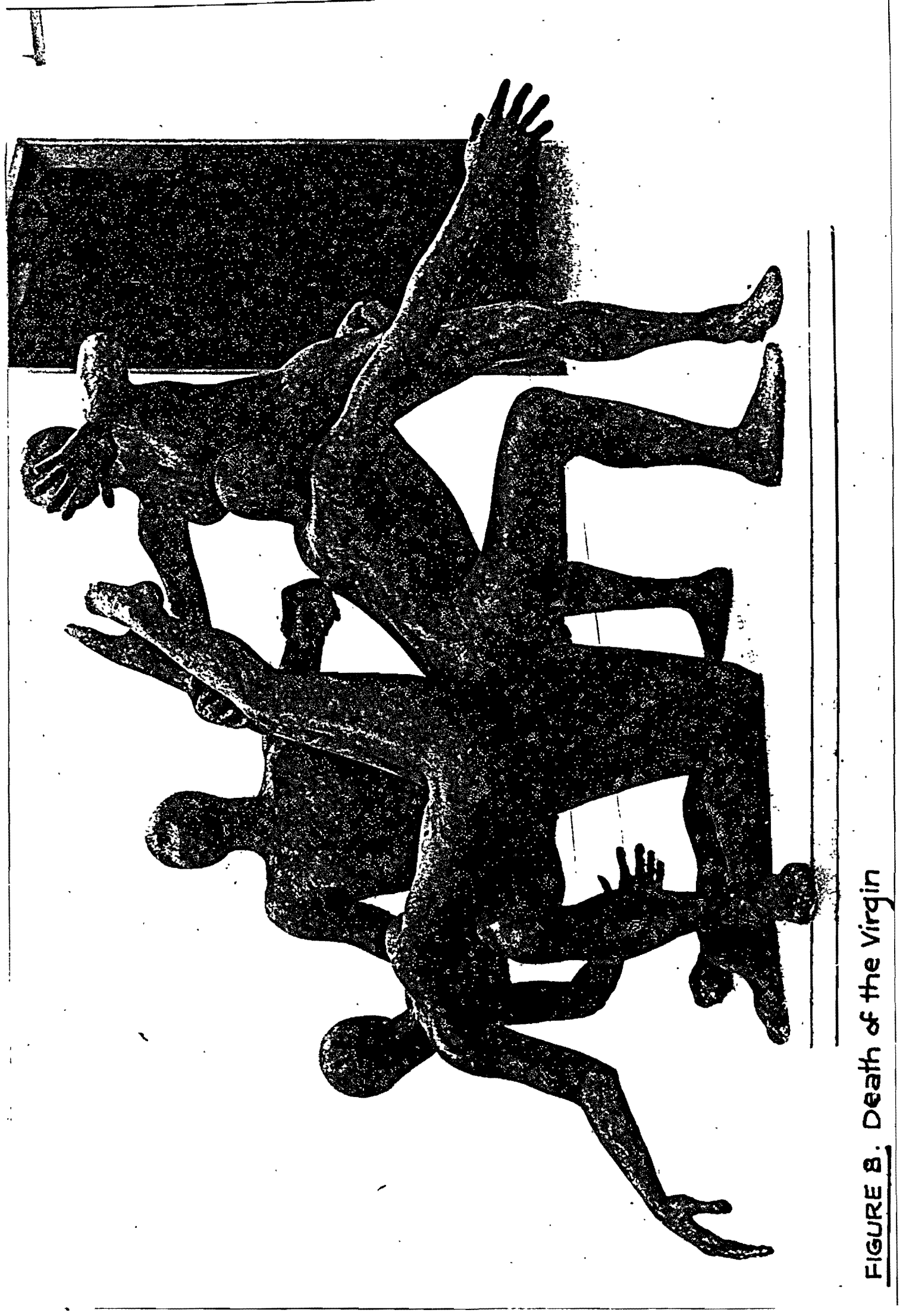




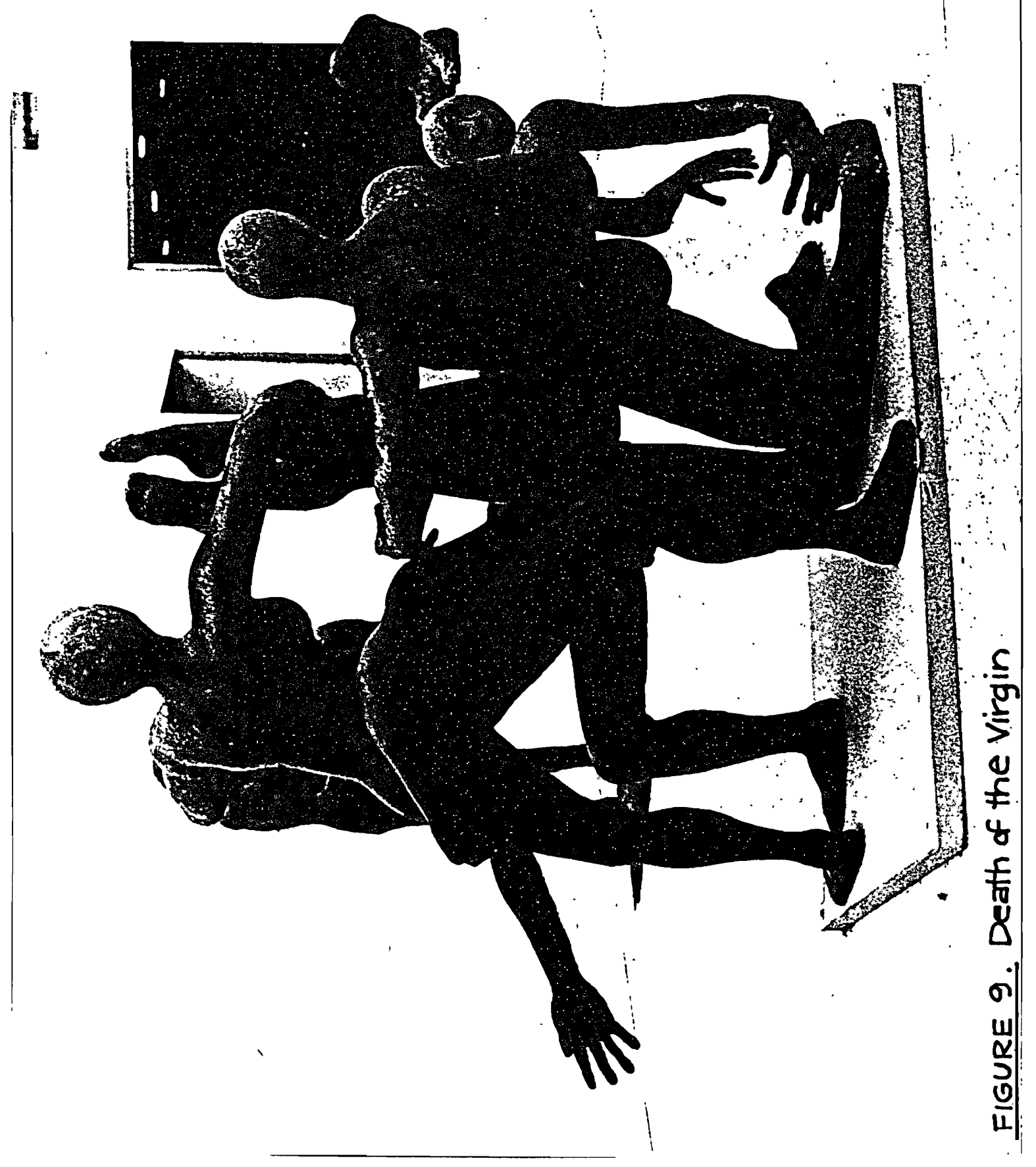




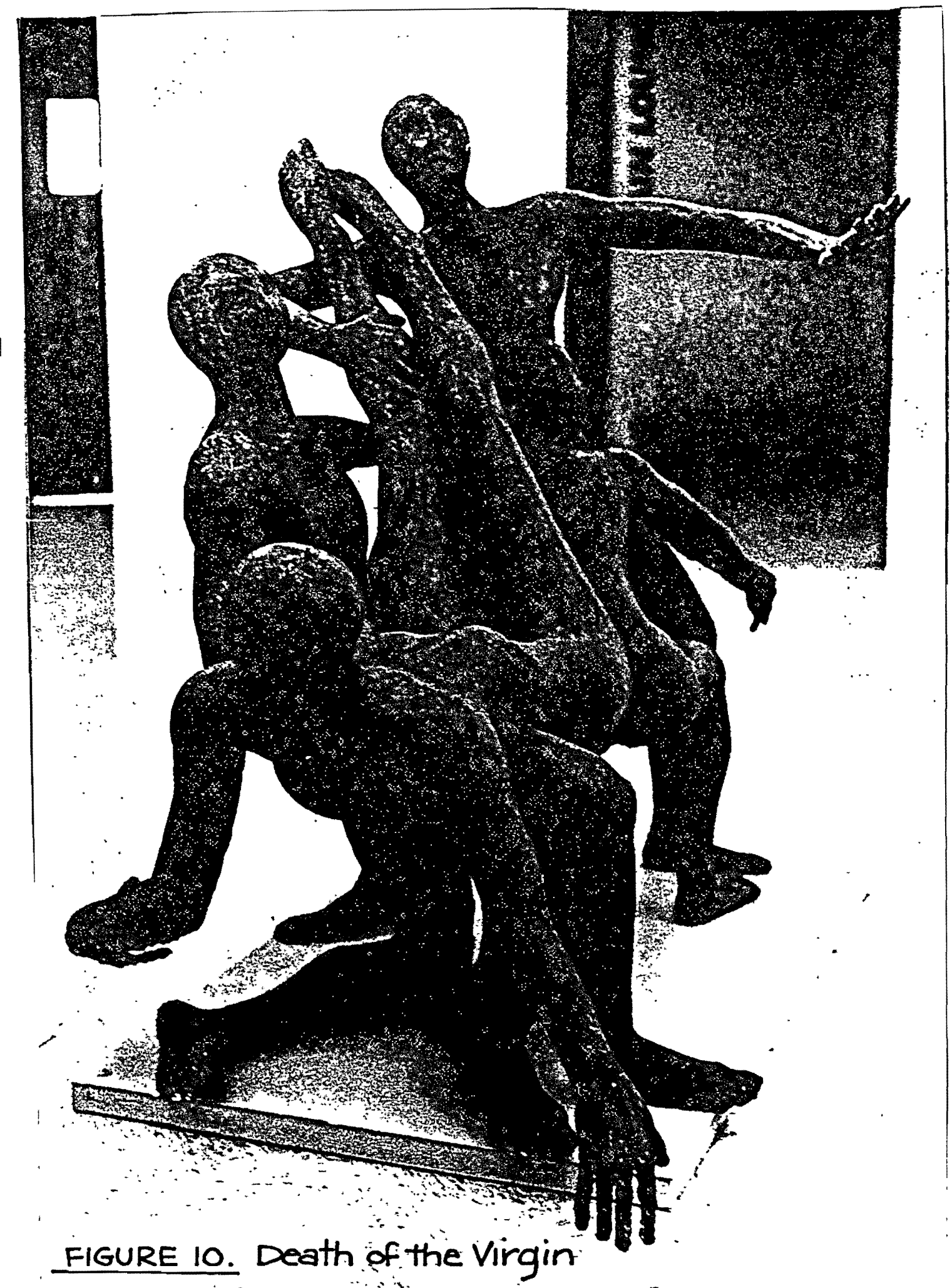




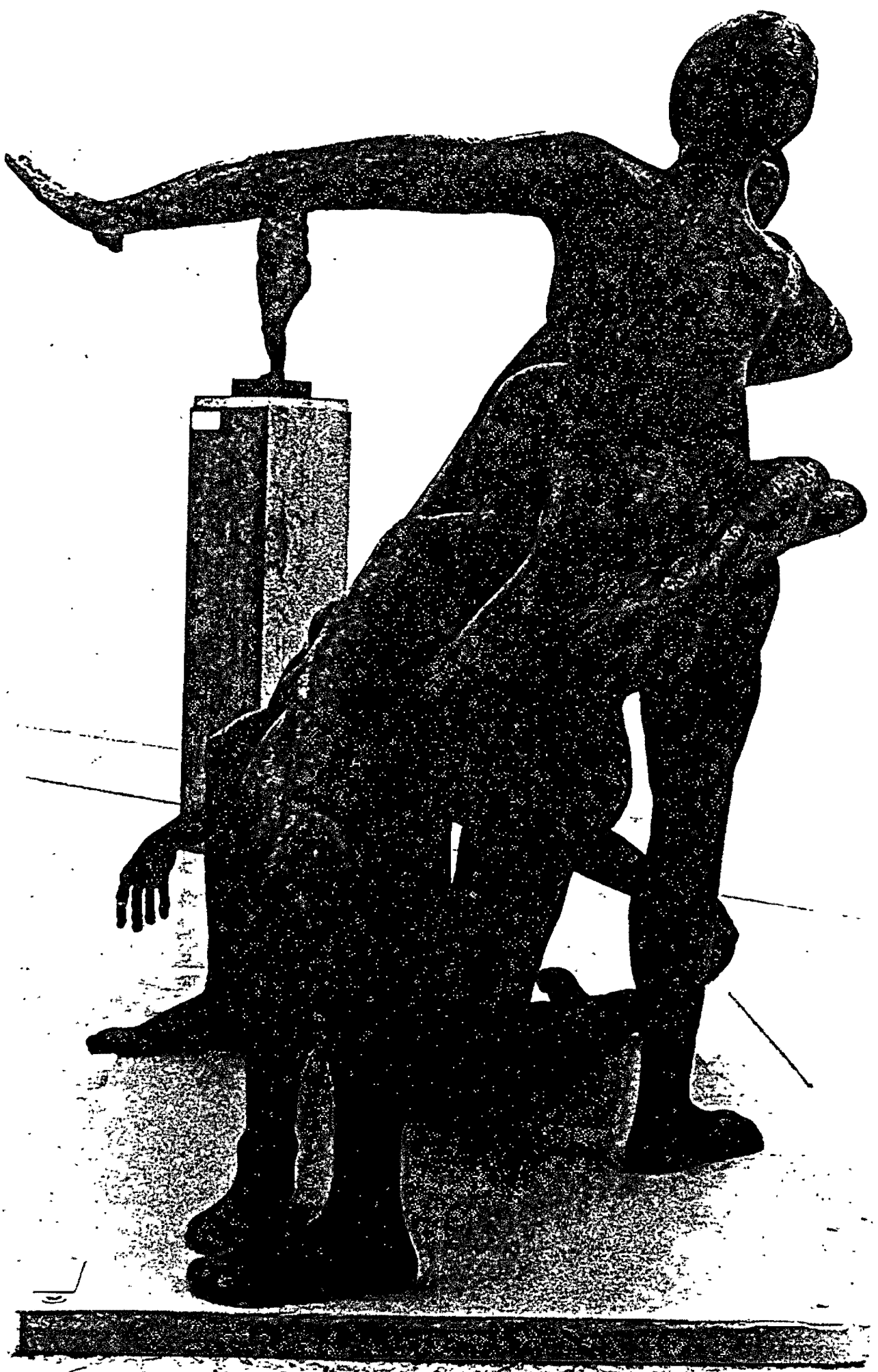

FIGURE II Death of The Vig in thes 


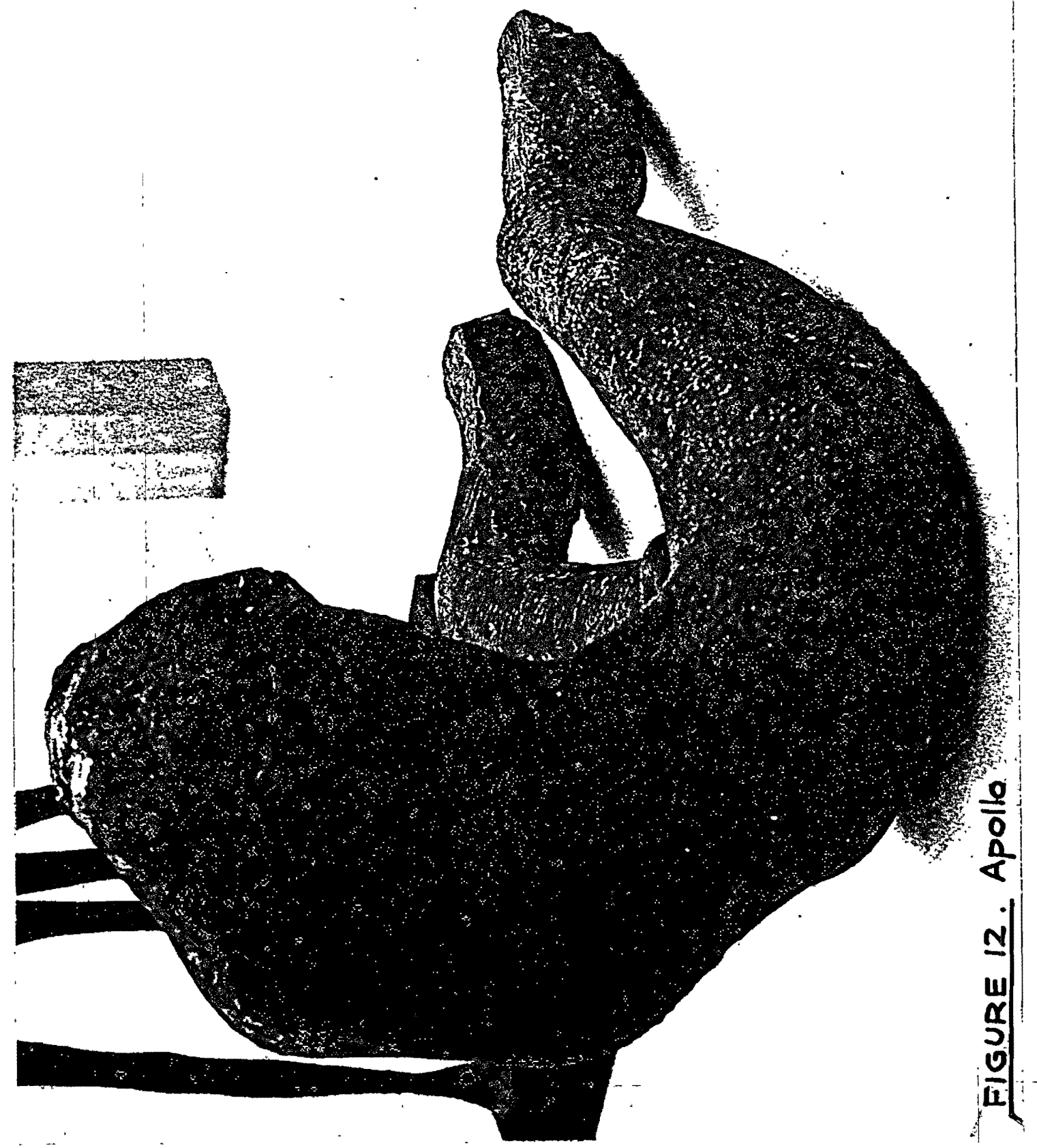




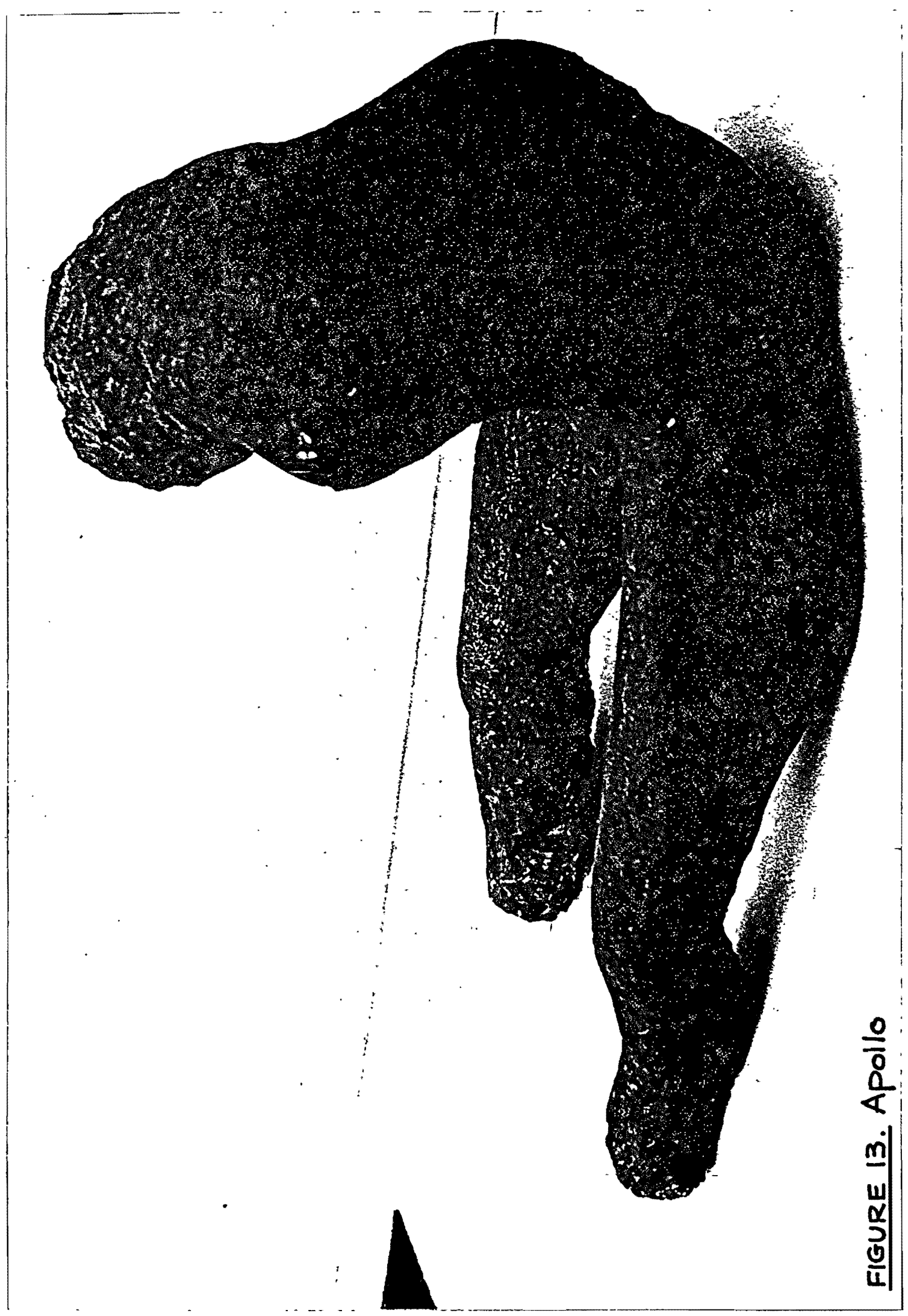




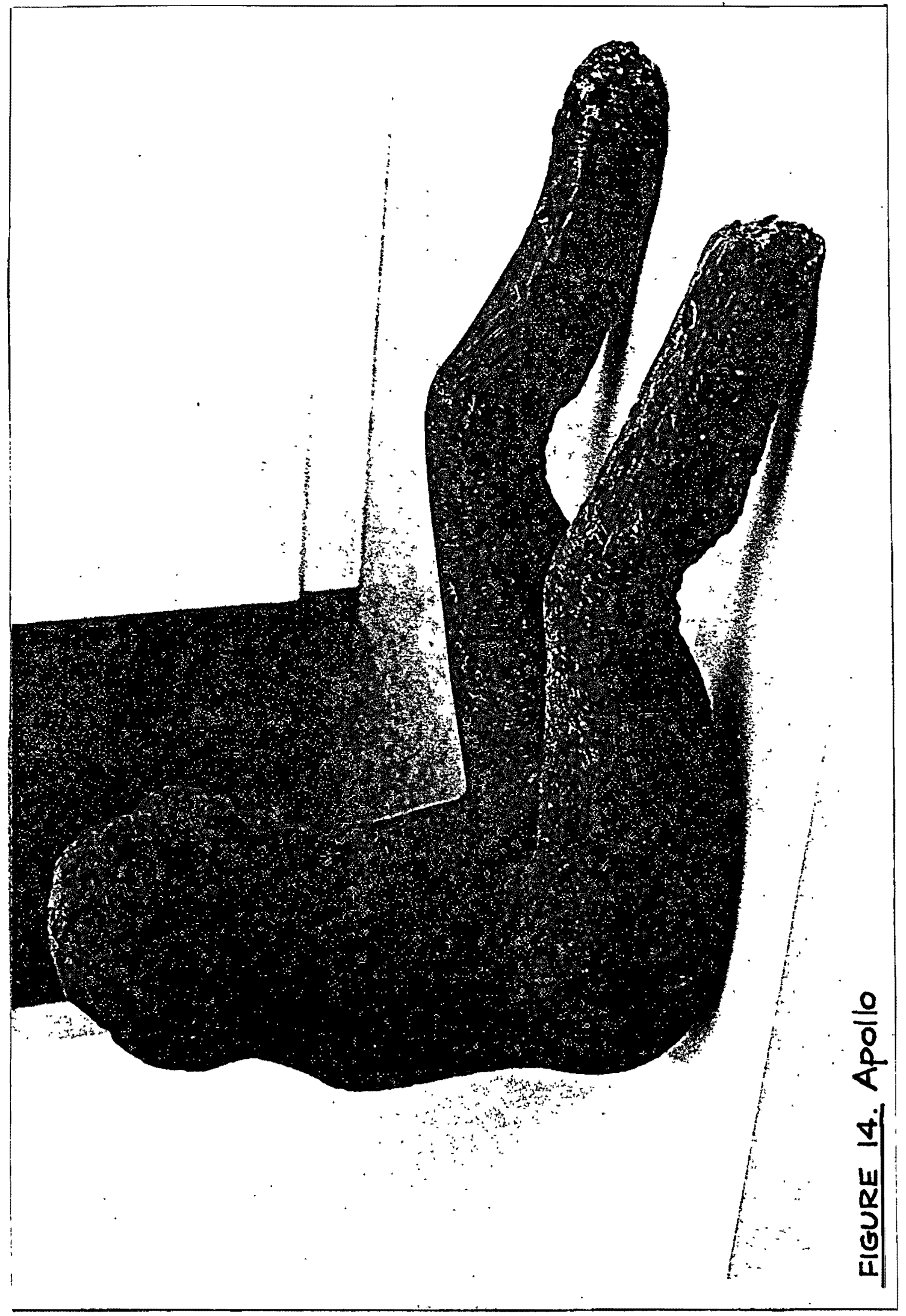




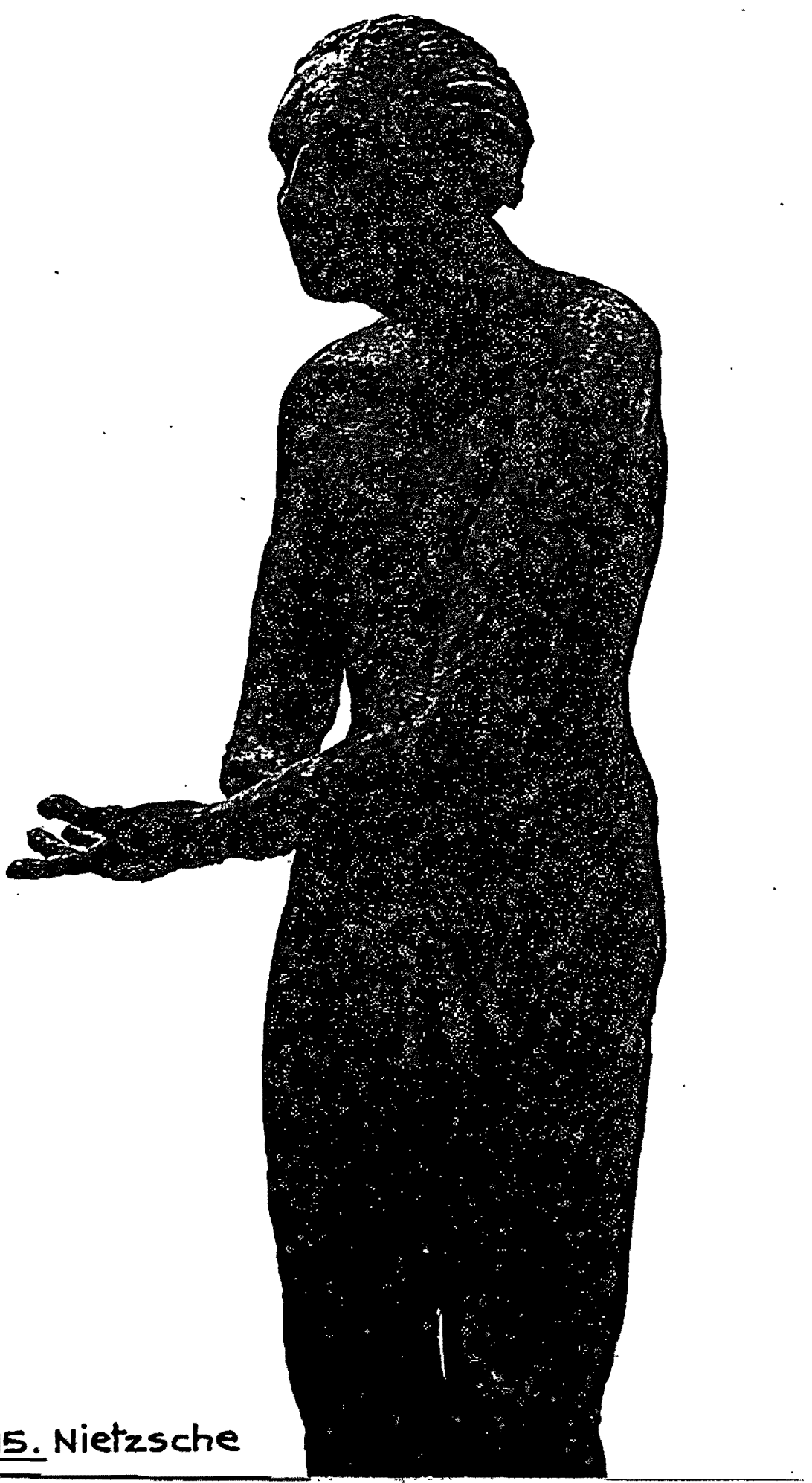

FIGURE 15. Nietzsche 
himself lived and died by his intellect. 
CHAPTER III

METHODS AND TECHNIQUES

My method of approach in sculpture follows the nature of my work; I try to allow for a flow of expressiveness which is true to my intuition, getting lost in forms and lines, and then I stop periodically to criticize and find the areas of consistency and inconsistency, weighing the polarities as I would expect a viewer to do. In the course of working, I try to balance the two of these so that the piece will be fresh and interesting but also understandable enough to hold the viewer's attention.

Of course working large demands a much more thorough conceptualization than working small simply because the permanent armiture must be much more precise. As a result, especially in my first piece, "Group of One", the large pieces tend to be less freely animated than the drawings or the bronzes.

The process involves welding 3/8" steel reinforcing bar to sheet steel or bolting the bar into wood as a central armiture. For the most part, I think of the steel bar as bones and add riuscles of wadded up newspapers wrapped in gauze or burlap onto the steel, and the plaster is a sort of thick skin. Then $I$ add and subtract plaster until the forms seem right. Patination is done with either oil or acrylic 
washes in colors built up to a dark grayish hue and then :. sprayed with varathane and waxed.

The two small bronzes were made in the traditional

lost wax method. The waxes were obtained from molds taken off of the original clay ("Modern Christ") and plasticene ("Roethke's Dance"). 


\section{CHAPTER IV}

\section{CRITIQUE AND CONCLUSIONS}

I usually don't believe evaluative satements on art. though I admit that there must be some absolute values that allow for agreement on the worth or different styles and artists. Theories often seem too pontifical, and I try to avoid making any absolutes even for myself. I make one exception in believing that art is an undefineable uncertain thing. We love it for that. So, not wishing to diminish the enigmatic energy from my work or anyone else's, I think that my evaluating should not try to define.

I see my work as closer to what I intend it to be in each successive piece, though I think, were I to reach that place, it would still be of interest to only a small group because it is so far from current advertised trends in sculpture. And despite my aim for an indefinite statement in the sense that the works intend to embody conflicting sentiments, I think it appears somewhat didactic. This is probably a result of its lack of abstraction and, especially in the four figure sculpture, its narrative appearance.

There is an academic quality to my work too that I will attempt to minimize in future sculptures. It is a conflict between anatomical correctness and abstract compostition which 
is not one of the conflicts I think important to present. The most successful of my pieces are the least complicated, not because one can only express that of which he is certain but because my own preconceptions and service of visual stereotypes gain the upper hand over a steadfast natural procedure when I try to control a number of extremes. 